\title{
Production of laccases, cellulases and xylanases of Pleurotus ostreatus grown in liquid-state fermentation
}

\section{Producción de lacasa, celulasa y xilanasa de Pleurotus ostreatus crecido en fermentación en estado líquido}

Edna María Hernández-Domínguez ${ }^{2,3}$, Carmen Sánchez ${ }^{1}$, Gerardo Díaz-Godínez ${ }^{1 *}$

${ }^{1}$ Laboratory of Biotechnology, Research Center for Biological Sciences, Universidad Autónoma de Tlaxcala, Tlaxcala, C.P. 90000. México.

${ }^{2}$ Higher Technological Institute of East the State of Hidalgo, Apan, Hgo. México

${ }^{3}$ Master of Biological Sciences. Universidad Autónoma de Tlaxcala.

*Corresponding author.

E-mail address: diazgdo@ @otmail.com (G. Díaz-Godínez).

Article history:

Received: 18 January 2017 / Received in revised form: 30 May 2017 / Accepted: 25 June 2017 / Published online: 1 July 2017.

https://doi.org/10.29267/mxjb.2017.2.2.169

\begin{abstract}
In this study, activities of laccases, xylanases and cellulases produced by Pleurotus ostreatus in liquid-state fermentation were evaluated. Three fermentations were done by triplicate where the carbon source was changed, one was made with glucose, in another was used carboxymethylcellulose and xylan and in the third the three carbon sources were added, in all cases, copper was added as inducer of laccases. The kinetic parameters of growth of the fungus were obtained. It was observed that this fungus produced the three enzymes evaluated; laccases showed the highest values $(34,240 \mathrm{U} / \mathrm{L})$ in the culture medium with glucose as sole carbon source. Cellulases showed their highest activity in the culture medium with xylan and carboxymethylcellulose (12,858 U/L) and xylanases in medium with glucose, carboxymethyl cellulose and xylan (27,153 U/L). Up to 4 isoform of laccases, 2 of xylanase and 2 of cellulases were observed by zymography.
\end{abstract}

Keywords: Cellulases, Fermentation, Laccases, Pleurotus ostreatus, Xylanases.

\section{RESUMEN}

En este estudio se evaluaron las actividades enzimáticas extracelulares de lacasas, celulasas y xilanasas producidas por Pleurotus ostreatus en fermentación líquida. Tres fermentaciones se realizaron por triplicado en el que se cambió la fuente de carbono, una se 
hizo con glucosa, en otro se utilizó carboximetilcelulosa y xilano y en la tercera se añadieron las tres fuentes de carbono, en todos los casos, se añadió cobre como inductor de lacasas. Se obtuvieron los parámetros cinéticos del hongo. Se lograron cuantificar todas las enzimas, siendo las lacasas las que mostraron las mayores actividades (34,240 U/L) en el medio de cultivo con glucosa como única fuente de carbono. Las celulasas mostraron su actividad más alta en el medio de cultivo con xilano y carboximetilcelulosa (12,858 U/L) y xilanasas en medio con glucosa, carboximetil celulosa y xilano (27153 U/L). Se lograron observar hasta 4 isoformas de lacasas y 2 de xilanasas y 2 de celulasas en los zimogramas.

Keywords: Celulasas, Fermentación, Lacasas, Pleurotus ostreatus, Xilanasas.

\section{INTRODUCTION}

It has been reported the presence of multiple lignocellulolytic isoenzymes, which could be the result of the expression of different genes or the same gene but with posttranslational changes such as proteolysis and glycosylation. The composition of the culture medium is also an important factor to induce the synthesis of isoenzymes, however, its catalytic properties may be similar but differ significantly in their physico-chemical characteristics (Mansur et al., 2003; Téllez-Téllez et al., 2005; Castro et al., 2013). Among these enzymes are laccases which are phenoloxidases that catalyze the oxidation of a wide range of phenolic compounds and aromatic amines, using molecular oxygen as electron acceptor, reducing it to water (Baldrian, 2006). These enzymes contain copper atoms, and are widely distributed in plants, insects, fungi and some bacteria (Massadeh et al., 2001). In fungi, the type and number of laccase isoforms depends on the species, of the culture medium and of production conditions (Sazuki et al., 2003; Téllez-Téllez et al., 2008). On the other hand, cellulases and xylanases are hydrolytic enzymes involved in breaking $\beta-1,4$ glycosidic bonds present in cellulose and hemicellulose, respectively. Production of these enzymes is subject to different regulatory mechanisms. Fungi and bacteria have showed a general model of regulation mainly controlled by two mechanisms; 1) induction holding cellulose and xylan for their natural substrates for cellulase and xylanase, respectively, and 2) repression by carbon sources of low molecular weight such as cellobiose and glucose. This model suggests the existence of a basal level of enzymes, wherein the microorganism synthesizes and exported to the cell surface, amounts of enzymes that initiate the hydrolysis of the substrate and produce small oligosaccharides to enter the cell, being the real inductors that automatically start transcription of genes (Gong, 2002).

Pleurotus ostreatus is an edible mushroom very appreciated for its flavor and nutritional value. It is a semi-anaerobic fungus that supports a $32 \% \mathrm{CO}_{2}$ when it grows in liquid media (Palmieri et al., 1997). Because of its few nutritional requirements and its easy adaptation to different growing environments, it requires simple and cheap techniques for cultivation and its wastes are turned into animal feed (Diamantidis et al., 2000). This fungus under controlled conditions has the ability to excrete extracellularly laccase, cellulase and xylanase, among others enzymes (Stajic et al., 2006). On the other hand, submerged or liquid fermentation (SMF), includes a variety of microbiological process with agitation, where biomass is completely surrounded by the liquid culture medium (Viniegra-González, 2003). This type of fermentation is widely used for the production of various metabolites of 
biotechnological interest, mainly enzymes (Díaz-Godínez et al., 2001; Téllez-Telléz et al., 2008; Álvarez-Cervantes et al., 2013; Hernández-Domínguez et al., 2014). In this study the activities of xylanase, cellulase and laccase produced by Pleurotus ostreatus grown in SMF were evaluated.

\section{MATERIALS AND METHODS}

\subsection{Organism and culture conditions}

Pleurotus ostreatus strain from the American Type Culture Collection (ATCC 32783) (Manassas, Virginia, U.S.A.) was used.

The processes were performed in Erlenmeyer flasks of $250 \mathrm{~mL}$ with $50 \mathrm{~mL}$ of liquid medium at $\mathrm{pH}$ 6.5. Three fermentations were done by triplicate where the carbon source was changed, a) the first one was made with $10 \mathrm{~g} \mathrm{~L}^{-1}$ glucose (M1), b) The second one (M2) contained glucose, carboxymethylcellulose and xylan $\left(5 \mathrm{~g} \mathrm{~L}^{-1}\right.$ of each) and c) the third one (M3) had carboxymethylcellulose $\left(5 \mathrm{~g} \mathrm{~L}^{-1}\right)$ and xylan $\left(5 \mathrm{~g} \mathrm{~L}^{-1}\right)$. The mineral composition was $\left(\mathrm{g} \mathrm{L}^{-1}\right)$ : $\mathrm{KH}_{2} \mathrm{PO}_{4}, 0.6 ; \mathrm{MnSO}_{4}-\mathrm{H}_{2} \mathrm{O}, 0.05 ; \mathrm{K}_{2} \mathrm{HPO}_{4}, 0.4 ; \mathrm{FeSO}_{4}-7 \mathrm{H}_{2} \mathrm{O}, 0.05 ; \mathrm{MnSO}-$ $\mathrm{H}_{2} \mathrm{O}, 0.05 ; \mathrm{ZnSO}_{4}-7 \mathrm{H}_{2} \mathrm{O}, 0.001$; y CuSO $0_{4}-5 \mathrm{H}_{2} \mathrm{O}, 0.25$ (Téllez-Téllez et al., 2008). All flasks were incubated at $25^{\circ} \mathrm{C}$ with orbital agitation $(120 \mathrm{rpm})$ and each $24 \mathrm{~h}$ were taken the samples. The fermentation and assays were carried out by triplicate.

\subsection{Biomass quantification and obtention of enzymatic crude extract}

The culture broth was considered as enzymatic crude extract (ECE) and was obtained by filtration and retention of biomass through Whatman filter paper Number 4 to constant weight. The dry biomass (X) was reported in g per L of ECE (Téllez-Téllez et al., 2008). Evolution of biomass $\mathrm{X}=\mathrm{X}(\mathrm{t})$ was done using the Velhurst-Pearl or logistic equation:

$$
\frac{d X}{d t}=\mu\left(1-\frac{X}{X_{\max }}\right) X
$$

where $\mu$ is the maximal specific growth rate, and Xmax is the maximal (or equilibrium) biomass level achieved when $\mathrm{dX} / \mathrm{dt}=0$ for $\mathrm{X} \geq 0$. The solution of Eq. 1 is as follows;

$$
X=\frac{X \max }{1+C e-\mu t}
$$

where, $C=\left(X_{\max }-X_{o}\right) / X_{o}, y X=X o$ the initial biomass value.

Estimation of kinetic parameters in the previous equation was done using a non-linear least square-fitting program, called "Solver" present in Excel electronic sheet (Microsoft) (DíazGodínez et al., 2001).

\subsection{Enzyme assays}




\subsubsection{Laccase activity}

Laccase activity was determined by changes in the absorbance at $468 \mathrm{~nm}$, using 2,6dimethoxiphenol as substrate (DMP). The assay mixture contained $950 \mu \mathrm{L}$ of substrate (2 $\mathrm{mM}$ DMP in $0.1 \mathrm{M}$ phosphate buffer at $\mathrm{pH}$ 6.5) and $50 \mu \mathrm{L} \mathrm{ECE}$, which was incubated at 40 ${ }^{\circ} \mathrm{C}$ for one min (Téllez-Téllez et al., 2008). One enzymatic unit (U) of laccase was defined as the amount of enzyme, which gives an increase of 1 unit of absorbance per min in the reaction mixture.

\subsubsection{Hydrolytic enzyme activity}

Xylanase and cellulase activities in ECEs were assayed by quantifying reducing sugars using the DNS method. The assay mixture contained $950 \mu \mathrm{L}$ of substrate $(0.5 \%$ birch xylan in $0.1 \mathrm{M}$ acetate buffer at $\mathrm{pH} 5.3$ and $1.0 \%$ carboxymethylcellulose in $0.1 \mathrm{M}$ acetate buffer at $\mathrm{pH} 5.0$ for xylanase and cellulase activities respectively) and $50 \mu \mathrm{L}$ of ECE and was incubated at $50{ }^{\circ} \mathrm{C}$. One enzymatic unit (U) of xylanase or cellulase was defined as the amount of enzyme that liberated $1 \mu \mathrm{mol}$ of xylose or glucose, respectively, per minute under assay conditions. The activity for all enzymes evauated was expressed in $\mathrm{U} \mathrm{L}^{-1}$ of ECE.

\subsection{Zymography analysis}

Laccase, xylanase and cellulase activities were detected in situ by zymograms (Raghukumar et al., 2004; Téllez-Téllez et al., 2012, Álvarez-Cervantes et al., 2013; Hernández-Domínguez, et al., 2014).

\section{RESULTS AND DISCUSSION}

P. ostreatus growth was evaluated for 21 days for each fermentation (Fig. 1). The "M1" fermentation showed a value of Xmax $=5.96 \mathrm{~g} \mathrm{~L}^{-1}$ and $\mu=0.016 \mathrm{~h}^{-1}$, M2 and M3 showed values of approximately $3.7 \mathrm{~g} \mathrm{~L}^{-1}$ for Xmax (38\% lower than the value of M1), however, values of $\mu$ were $12.5 \%$ greater (approximately $0.018 \mathrm{~h}^{-1}$ ). In reports where was grew the same strain in SMF with $10 \mathrm{~g} \mathrm{~L}^{-1}$ glucose but using ammonium sulfate as nitrogen source (Beristain et al., 2008) or in cultures at pH 6.0 (Tellez-Tellez et al., 2008) values of Xmax were of 2.22 and $7.8 \mathrm{~g} \mathrm{~L}^{-1}$, respectively. This results show that the mixture of carbon sources produces a higher growth rate but less biomass, which could be because the mainly carbon sources in the nature for this fungus are polysaccharides. 

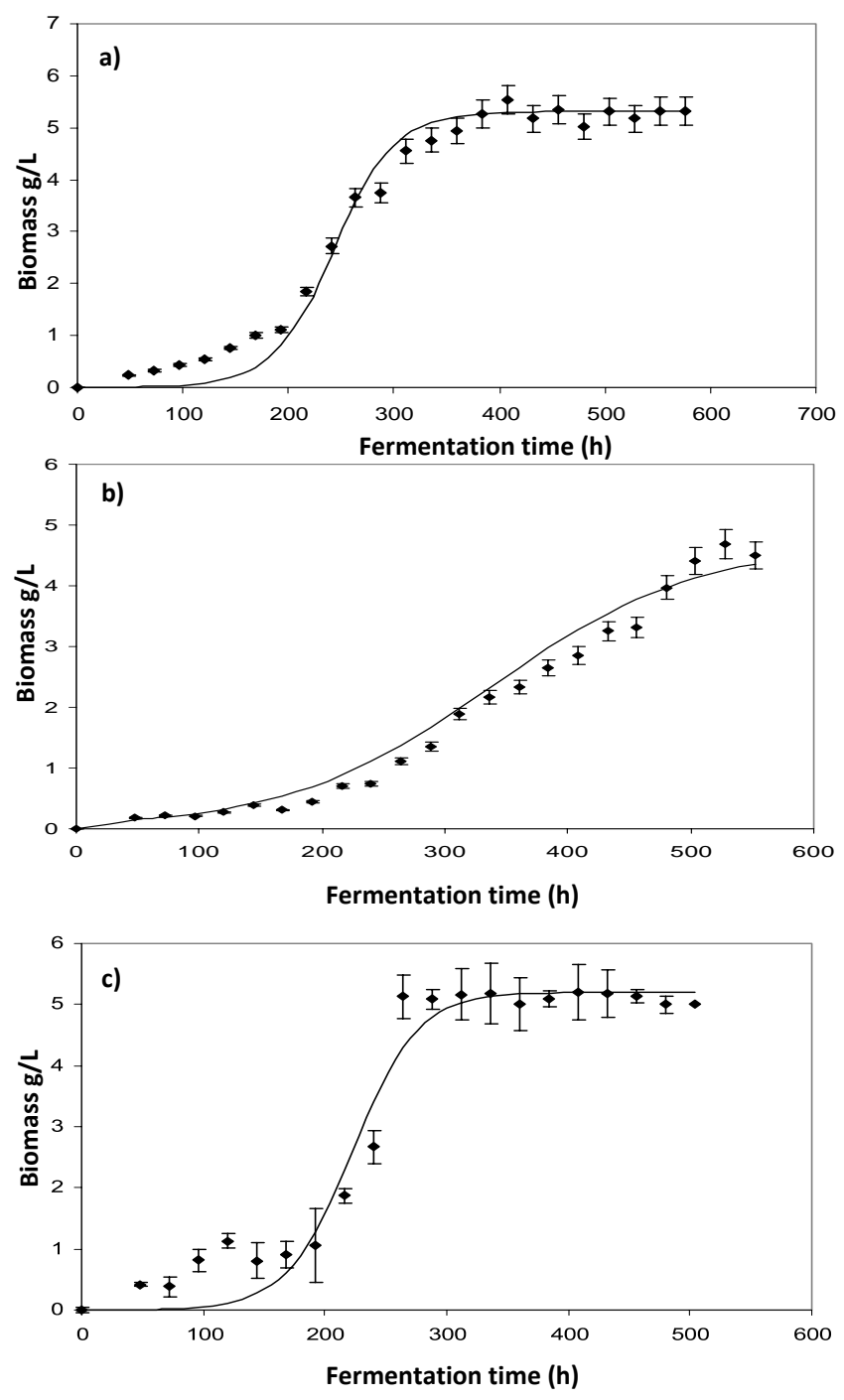

Fig. 1. Biomass evolution of Pleurotus ostreatus grown in liquid-state fermentation in M1 (a), M2 (b) and M3 (c) media.

Tlecuitl-Beristan et al,. (2008) reported the maximum laccase activity from $P$. ostreatus ATCC 32783 of 12,196 U L-1, whereas Tellez-Tellez et al. (2008) reported 13,000 $\mathrm{U} \mathrm{L}^{-1}$ for the same strain; enzymatic activity obtained in this study showed higher values than those reported above, since the maximum activity in M1 M2 and M3 were of 34,240, 31,840 and $30,680 \mathrm{U} \mathrm{L}^{-1}$, respectively. It is noteworthy that in all three cases the maximum activity of laccases was presented at the stationary phase of growth of the fungus, which coincides with the time when the fungus consumes the carbon source, it is suggests that these carbohydrates can cause catabolite repression in the production of such enzymes. AlvarezCervantes et al. (2016) evaluated the ligninolytic activity of P. ostreatus grown in solidstate fermentation using glucose as the sole carbon source, reporting the maximum laccase activity of $18,030 \mathrm{U} \mathrm{L}^{-1}$. In this study, the cellulase activity was evaluated in the three culture media, the medium M3 showed the highest enzyme activity with a value of 12,585 $\mathrm{UL}^{-1}$, followed by media M1 and M2 with maximum activity values of 8,158 and 7,659 
$\mathrm{UL}^{-1}$ respectively. Xylanase activity was higher in the medium M2 with a maximum value of 1,597 $\mathrm{UL}^{-1}$, followed by M3 and M1 with maximum values of 1,224 and $679 \mathrm{UL}^{-1}$ respectively. This suggests that the xylanases and cellulases are constitutive enzymes and increase their activity in the presence of inducers but the glucose not allow higher activity values and the laccases showed a basal level of activity. This is the first time where xylanase and cellulase activities were evaluated in the strain P. ostreatus ATCC 32783, however, the production of these enzymes in other microorganisms has been reported, as the study where Trichoderma resei produced xylanases with maximum values of activity of $25 \mathrm{UL}^{-1}$ (Raghukumar et al., 2004).

Zymograms are a useful tool for determine both extracellular and intracellular isoenzymes, because only proteins with catalytic activity of interest are evident. The laccases zymogram shows 4 isoenzyes in the three fermentations at $\mathrm{pH} 4.5$ (Figure 2).

A
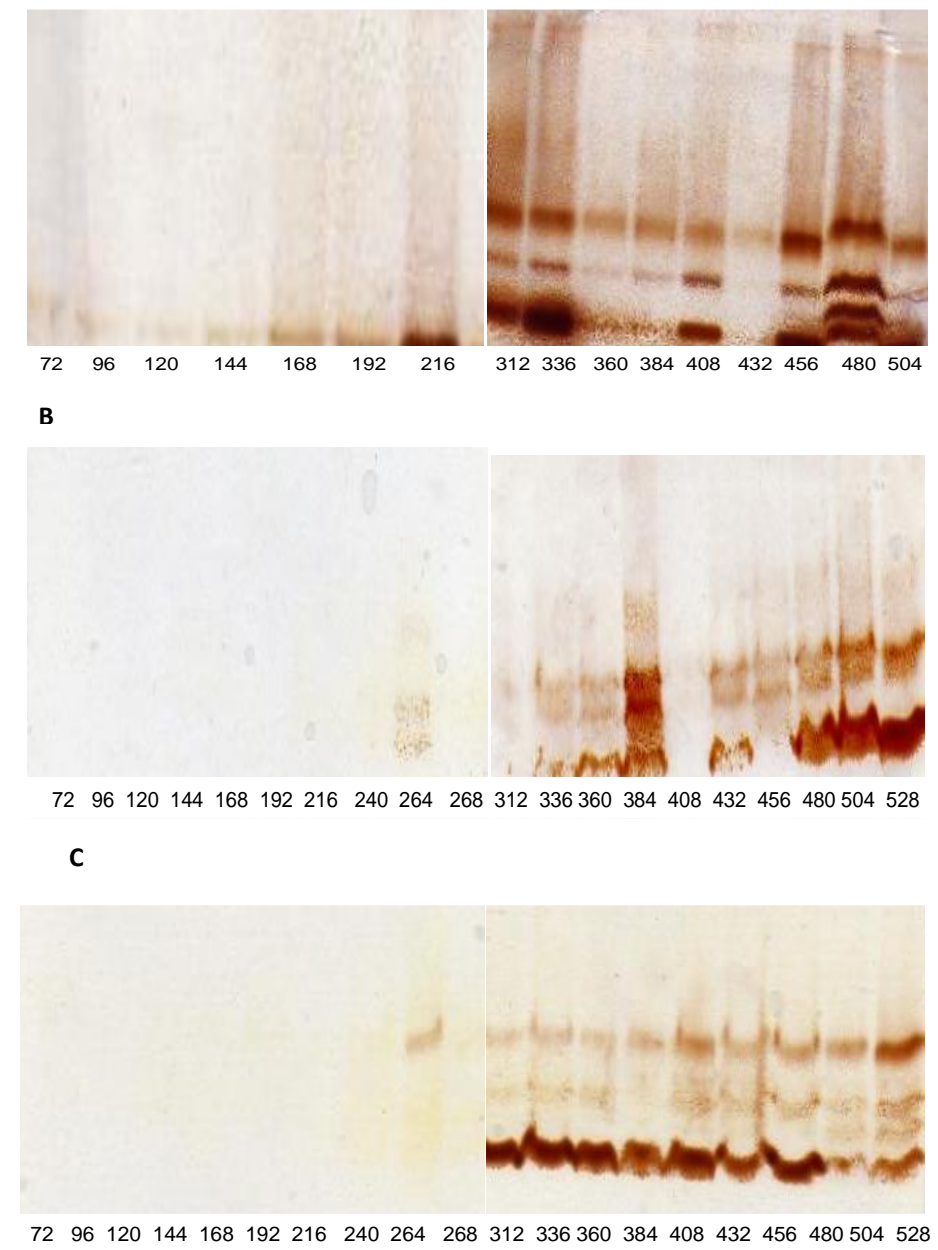

Fig. 2. Laccase zymograms of Pleurotus ostreatus grown in M1 (A), M2 (B) and M3 (C). The numbers under the gels are the sampling time. 
Velazquez et al., (2014) reported up to two isoforms of laccase produced by $P$. ostreatus grown in solid-state fermentation at $\mathrm{pH}$ 3.5, 4.5 and 6.5. Alvarez-Cervantes et al., (2016) reported up to 4 laccases isoenzynes of $P$. ostreatus grown at $\mathrm{pH} 4.5$ in solid-state fermentation with glucose as the sole carbon source. In this study, two isoforms both xylanase and cellulase were observed (Figure 3 ).

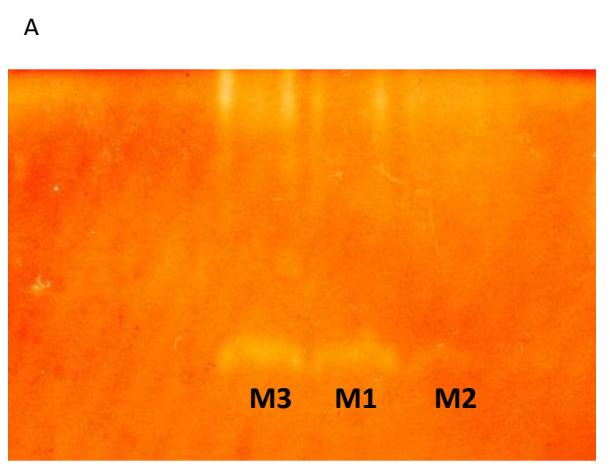

312336360384408432456480504528

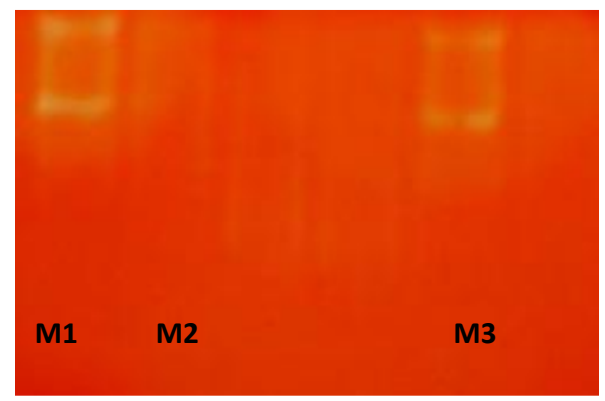

312336360384408432456480504528

Fig. 3. Cellulase (A) and Xylanase (B) zymograms of Pleurotus ostreatus grown in SMF. The ECE at the time for maximal activity of each media were used for zymograms.

It has been reported that filamentous fungi are the best source of lignocellulolytic enzymes and its production is regulated by its corresponding substrate (Amore et al., 2013). This is the first report on the production of extracellular lignocellulolytic enzymes of $P$. ostreatus ATCC 32783 in liquid culture.

\section{ACKNOWLEDGEMENTS}

Thanks to the Research Center for Biological Sciences at the Autonomous University of Tlaxcala and the National Council for Science and Technology for the scholarship awarded to Hernández-Domínguez.

\section{REFERENCES}

Álvarez-Cervantes, J., Hernández-Domínguez, EM., Arana-Cuenca, A., Díaz-Godínez, G., Mercado-Flores, Y. 2013. Purification and characterization of xilanasa srxl1 from Sporisorium reilianum grown in submerged and solid-state fermentation. Bioresoruces 8(4): 5309-5318.

Álvarez-Cervantes, J., Sánchez, C., Díaz, R., Díaz-Godínez, G. 2016. Characterization of production of laccases, cellulases and xylanases of Pleurotus ostreatus Grown solid-state fermentation using an inert support. Revista Mexicana de Ingeniería Química 15(2): 226232.

Amore, A., Giacobbe, S. \& Faraco, V. 2013. Regulation of cellulase and hemicellulase gene expression in fungi. Current Genomics 14(3): 230-249.

Baldrian, P. 2006. Fungal laccases occurrence and properties. FEMS Microbiology 
Reviews 30(2): 215-242.

Castro, A., González, I., Tzompantzi, F. \& Viniegra-González, G. 2013. Influence of the type of support and immobilization on the activity and stability of laccase enzyme (Trametes versicolor). Revista Mexicana de Ingeniería Química 12(2): 241-255.

Díaz-Godínez, G., Soriano-Santos, J., Augur, C. \& Viniegra-González, G. 2001. Exopectinases produced by Aspergillus niger in solid-state and submerged fermentation: a comparative study. Journal of Industrial Microbiology and Biotechnology 26(3): 271-275.

Hernández-Domínguez, E. M., Rios-Latorre, R. A., Álvarez-Cervantes, J., Loera-Corral, O., Roman-Gut 1errez, A. D., DÍaz-GodÍnez, G. \& Mercado-Flores, Y. 2014. Xylanases, cellulases and acid protease produced by Stenocarpella maydis grown in solid-state and submerged fermentation. Bioresources 9(4): 2341-2358.

Mansur, M., Arias, M. E., Copa-Patiño, J.L., Flardh, M. \& González, A. E. 2003. The White-rot fungus Pleurotus ostreatus secretes laccase isoenxymes with different substrate specificities. Mycologia 95(3): 1013-1020.

Massadeh, MI., Yusoff, W. M. W., Omar, O. \& Kader, J. 2001. Synergism of cellulase enzymes in mixed culture solid substrate fermentation. Biotechnology Letters 23(2): 17711774.

Téllez-Téllez, M., Sánchez, C., Loera, O. \& Díaz-Godínez, G. 2005. Differential patterns of constitutive intracellular laccases of the vegetative phase of Pleurotus species. Biotechnology Letters 27(2): 1391-1394.

Téllez-Téllez, M., Fernández, FJ., Montiel- González, AM., Sánchez, C. and DíazGodínez, G. 2008. Growth \& laccase production by Pleurotus ostreatus in submerged and solid- state fermentation. Applied Microbiology and Biotechnology 81(3): 675-679.

Tlecuitl-Beristain, S., Sánchez, C., Loera, O., Robson, G. D. \& Díaz-Godínez, G. 2008. Laccases of Pleurotus ostreatus observed at different phases of its growth in submerged fermentation: production of a novel laccase isoform. Mycology Resources 112(2): 10801084.

Raghukumar, C., Muraleedharan, U., Gaud, VR. \& Mishara, R. 2004. Xylanases of marine fungi of potential use for biobleaching of paper pulp. Journal of Industrial Microbiology and Biotechnology 31(3): 433-441.

Suzuki, T., Endo, K., Ito, M., Tsujibo, H., Miyamotyo, K. \& Inamori, Y. 2003. A termostable laccase from Streptomyces lavendulae ren-7: purification, characterization, nucleotide sequence and expression. Bioscience Biotechnology and Biochemistry 6(2): 2167-2175.

Viniegra-González, G., Favela-Torres, E., Aguilar, C. N., Rómero-Gómez, S. J., D íazGodínez, G. \& Augur, C. 2003. Advantages of fungal enzyme production in solid state over liquid fermentation systems. Biochemical Engineering Journal 13(3): 157-167. 